\title{
Determinants of Loss to Follow Up (LTFU) With HIV Pregnant Women on Antiretroviral Therapy in Programs Prevention for Mother to Child Transmission (PMTCT) in Jayapura Regional Public Hostipal: A Qualitative Study
}

\author{
$1^{\text {st }}$ Yurmianti Rante Allo \\ Midwifery Department \\ Poltekkes Kemenkes Jayapura \\ Jayapura, Indonesia \\ yurmiranteallo@gmail.com
}

\author{
$2^{\text {nd }}$ Susana Ramandey \\ Midwifery Department \\ Poltekkes Kemenkes Jayapura \\ Jayapura, Indonesia \\ susanaramandey@gmail.com
}

\author{
$3^{\text {rd }}$ Sri Wahyuni \\ Midwifery Department \\ Poltekkes Kemenkes Jayapura \\ Jayapura, Indonesia \\ sriwahyunijayus@gmail.com
}

\begin{abstract}
Adherence to antiretroviral therapy (ARV) is the key to suppressing the development of HIV disease, reducing the risk of drug resistance, improving overall health, improving quality and survival and reducing the risk of HIV transmission. A mother must comply with ARV therapy to prevent transmission from mother to child. Loss to follow up with antiretroviral (ARV) drugs in mothers can increase the risk of HIV transmission from mother to child. This study aims to ascertain the determinants of loss to follow up of HIV pregnant women taking ARV therapy in Preventing Motherto-Child Transmission (PMTCT) at the Jayapura Regional General Hospital. This research uses a qualitative method with a case study approach. Data collection was carried out through in-depth interviews, observation, focus group discussions (FGD), field notes and documentation with 7 HIV pregnant women who were recorded as not compliant to undergo ARV therapy. Data analysis was performed descriptively using triangulation and content analysis methods. The results of this study reveal that the determinants of loss to follow up with ARV therapy are low vulnerability and perception of illness, the presence of stigma and discrimination that is still high and low social support. With the results of the above study, one conclusion is drawn that the determinants loss to follow up of pregnant women with ARV therapy will add many new cases of HIV in Papua. So that if it is not handled better, then the Three Zero target in $\mathbf{2 0 3 0}$ will only remain a discourse
\end{abstract}

Keywords - Public Support; Loss To Follow Up, Pregnant Women HIV, PMTCT, ARV Therapy

\section{INTRODUCTION}

HIV/AIDS is now a health problem that threaters Indonesia and many countries around the world. HIV is a virus that infects cells of the immune system. Destroys or damage it's function. HIV infection make progressive damage ti the immune system. Thus causing AIDS [1]

HIV/AIDS sufferers need ARV treatment to reduce the amount of HIV virus in the body. So is doesn't enter to the AIDS stage and to prevent opportunistic infections and the complications[2]
Papua province is province with third number of HIV case finding in Indonesia. Based on monthly reports as of March 2019. Data on medical services for people with HIV/AIDS the number of ODHA (HIV/AIDS sufferers) who entered treatment 3.955 people, while number of ODHA who had ARV is 21.788 people[3]

People with HIV/AIDS on antiretroviral (ARV) therapy (routinely receive ARVs) is 6.534 people. HIV/AIDS sufferers that loss to follow up is 7.597 people. Died is 2.956 people and stop is 168 people. Until the 1st quarter 2019 through AIDS surveillance data sources in the Papua Provincial health department is 40.805 cases and the most in Nabire regency with a total of 7.436 cases. Jayapura city is 6.765 cases , and Jayawijaya regency is 6.242 cases[3].

Data obtained from medical records in the Voluntary, Counselling, and Testing (VCT) room and midwifery clinics showed that the number of pregnant woman diagnosed with HIV positive from 2016 to June 2019 was 13.953 cases and the number of treated as many as 4428 , while the number of HIV cases from Januari to Oktober was 330, inside there were 66 pregnant women and all had received ARV therapy. From 66 cases, have given birth to 27 people, 1 baby infected with HIV, 39 pregnant women but still loss to follow up [4]. This study aims to ascertain the determinants of loss to follow up of HIV pregnant women taking ARV therapy in Preventing Mother-to-Child Transmission (PMTCT) at the Jayapura Regional General Hospital.

\section{RESEARCH METHOD}

This type of research is descriptive qualitative. Analysis of the date in this research cases content analysis that is analysis based on the contents of the interview are categorizied according to the themes that emerge[5]. Sampling technique in the research used purposive sampling technique, the sample found during the research were $7 \mathrm{HIV}$ positive pregnant women who were not compliant with ARV therapy ask such main informant, additions informants is 8 people VCT officers and 1 person from the midwifery clinic, so that number of informants were 16 people. Data analysis 
was performed descriptively using triangulation and content analysis methods. The five right of human subjects in research used in this research such as Respect for Autonomy, Privacy or dignity, Anonymity dan Confidentialy, Justice, Beneficence dan Nonmaleficence[6].

\section{RESULT AND DISCUSSION}

A. The main characteristics of the informant were pregnant women who suffer from HIV and undergoing PMTCT program in this research are as follows:

TABLE I. CHARACTERISTIC THE MAIN ON INFORMAN

\begin{tabular}{|l|c|c|l|l|l|l|l|}
\hline $\begin{array}{c}\text { Info } \\
\text { rma } \\
\mathbf{n}\end{array}$ & $\begin{array}{c}\text { se } \\
\mathbf{x}\end{array}$ & $\begin{array}{c}\text { Ag } \\
\mathbf{e}\end{array}$ & $\begin{array}{l}\text { Educat } \\
\text { ion }\end{array}$ & $\begin{array}{l}\text { Profes } \\
\text { sion }\end{array}$ & $\begin{array}{l}\text { Religio } \\
\mathbf{n}\end{array}$ & Address & Place \\
\hline N1 & M & 37 & $\begin{array}{l}\text { High } \\
\text { school }\end{array}$ & Trader & $\begin{array}{l}\text { Christi } \\
\text { an }\end{array}$ & Paldam & $\begin{array}{l}\text { Private } \\
\text { house }\end{array}$ \\
\hline N2 & M & 35 & $\begin{array}{l}\text { High } \\
\text { school }\end{array}$ & Seller & $\begin{array}{l}\text { Mosle } \\
\text { m }\end{array}$ & Hamadi & $\begin{array}{l}\text { contrac } \\
\text { t }\end{array}$ \\
\hline N3 & M & 44 & $\begin{array}{l}\text { Primar } \\
\text { y } \\
\text { school }\end{array}$ & $\begin{array}{l}\text { House } \\
\text { wife }\end{array}$ & $\begin{array}{l}\text { Christi } \\
\text { an }\end{array}$ & Dok II & $\begin{array}{l}\text { Private } \\
\text { house }\end{array}$ \\
\hline N4 & M & 23 & $\begin{array}{l}\text { High } \\
\text { school }\end{array}$ & $\begin{array}{l}\text { House } \\
\text { wife }\end{array}$ & $\begin{array}{l}\text { Christi } \\
\text { an }\end{array}$ & Dok 9 & Rent \\
\hline N5 & M & 31 & $\begin{array}{l}\text { High } \\
\text { school }\end{array}$ & $\begin{array}{l}\text { House } \\
\text { wife }\end{array}$ & $\begin{array}{l}\text { Christi } \\
\text { an }\end{array}$ & Dok II & Rent \\
\hline N6 & M & 22 & $\begin{array}{l}\text { High } \\
\text { school }\end{array}$ & $\begin{array}{l}\text { House } \\
\text { wife }\end{array}$ & $\begin{array}{l}\text { Christi } \\
\text { an }\end{array}$ & Dok II & $\begin{array}{l}\text { Private } \\
\text { house }\end{array}$ \\
\hline N7 & M & 24 & $\begin{array}{l}\text { Under } \\
\text { graduat } \\
\text { e }\end{array}$ & $\begin{array}{l}\text { House } \\
\text { wife }\end{array}$ & $\begin{array}{l}\text { Christi } \\
\text { an }\end{array}$ & Tg Ria & $\begin{array}{l}\text { Private } \\
\text { house }\end{array}$ \\
\hline
\end{tabular}

Based on Tabel 1 The youngest is 22 years old and the oldest is 44 years old. Most jobs are housewives, most marital marriages are legal and two people don't have legal partner. The duration of detection of HIV is 5 years and the length of times it is not compliant with ARVs all over 3 months. The lowes education is primary school and the highest under graduate.

Most of 7 informants were infected from husband/their partners. Informan $\mathrm{N} 5$, have experience with having 3 children. The first child is infected because he doesn't know the PMTCT program and while pregnant with a second child the husband moved to Jayapura from Wamena and was introduced to the PMTCT program through the VCT clinic of the Jayapura regional Public Hospital but only did ARV therapy. For 6 months and after the baby was born, at 2 weeks the baby was declared to have a heart leak. Then in the third pregnancy the officer tried to conuince the N5 informants VCT of the importance of PMTCT and mother obediently follows so that when the third baby is born, baby is healthy and grow well until this day he has two months old while waiting for the age of 18 months old to take an HIV test.

\section{B. Characteristics of triangulation Informants}

TABLE II. CHARACTERISTICOF TRIANGULATION INFORMANTS FOR HEALTH WORKRS

\begin{tabular}{|c|c|c|c|c|}
\hline $\begin{array}{c}\text { Inform } \\
\text { ants }\end{array}$ & Age & $\begin{array}{c}\text { Relationship with } \\
\text { informants }\end{array}$ & $\begin{array}{c}\text { Educati } \\
\text { on }\end{array}$ & Profession \\
\hline T1 & 47 & Health worker & S2 & Nurse \\
\hline T2 & 48 & Health worker & S2 & Doctor \\
\hline T3 & 48 & Health worker & S1 & Nurse \\
\hline T4 & 57 & Health worker & D3 & Midwife \\
\hline T5 & 40 & Health worker & S1 & Nurse \\
\hline T6 & 38 & Health worker & D3 & Nurse \\
\hline T7 & 37 & Health worker & D3 & Nurse \\
\hline T8 & 35 & Health worker & D3 & Nurse \\
\hline T9 & 35 & Health worker & S1 & Nurse \\
\hline
\end{tabular}

In the research, triangulation informants are 9 people, including 8 people from the VCT clinic and 1 from emergency department comprehensive Neonatal Obstetric Treatment which is coded T1-T9.

Based interviews on May 19, 2020 to the ninth supporting informant consisting of various health education backgrounds, some of whom were doctors, midwife and nurses. Some of them have started working in VCT clinic was opened in 2004, the first in Papua which was located in Jayapura Regional Public Hospital.

\section{The results and discussion of research that led to non- compliance as follow:}

1) Perception of vulnerability.

Perception of vulnerability include sexual activity undertaken condom use risk of transmission and risk of contracting diseases other than HIV. The following result of research on perceptions of vulnerability:

\section{a) Sexual activity}

A small number of informants have risk sexual relations by changing partners. The following excerpt statement from the informants:

"eee so and so... a little sick, usually with boyfriend, not use condom, but no more" (N4,W1,May 5, 2020).

"Yes, if we at home, usually we often going out, we don't use condom husband do not like, angry." (N6,W1,May 14,2020)

The acknow ledment of the informants above is justified by the statement of triangulation of health worker who know the sexual activities at risk of the main informant.

"she still has sex with some of her male friends in the complex where she lives. So are of the two positive ones the last sex with N4, so I call her the infections. (T1,FGD1 May 19,2020)

b) Use of Napza

All of informants said that they never using napza (Narkotika, Psychotropic addictive subtances).

The follow is an excerpt from the statement of the informant:

“I never used Drugs. Never. “(N1,W1,April 9,2020) 
"Never, sure ? yes , nurse, I am at home and just at stall." (N2,W1, April 23,2020)

“never, I don't use napza and others" (N7, W1, April 14, 2020)

\section{c) Use Condom}

A small number of informants claimed that they had sexual relations using condoms. This means that a small number of informants feel vulnerable to transmitting HIV to their partners it they don't use condoms in their sexual activities. Following an excerpt from informant statements:

"Yes, we still do, because we are husband and wife, but we use condom." (N3, W1, May 5, 2020)

A small number of informants at risk of transmitting HIV is manifested in the behavior of condom use in every sexual relationship the following snippet statement informant:

"usually with boyfriend, don't use condom " (N4, W1, May 5, 2020)

"we don't use condom husband doesn't like, angry" (N6, W1, May 14, 2020)

\section{d) Risk of getting discases other than HIV.}

A small number of informants are not aware of the risk of illness if they still don't take ARV therapy the informant feels healthy as someone who doesn't have a diseases. The following snippet statement informant:

"The body is still fresh. So still strong to go anywhere "(N4, W1, May 5, 2020)

"actually, I will not take my medicine today. I will not take medicine because if I take medicine I get dizzy, nausea and vomiting “(N7, W1, May 14, 2020)

Most of the informant poor knowledge of HIV/AIDS and ARV. Observation and surveillance, made during the research found outreach activities carried out to HIV infected patients were limited to counselling without the use of assistive devices such as flipcharts or others and laying banners about HIV and laying out brochures and leaflets placed in places that were less accessible to patients, so according to researchers informantion and knowledge about HIV/AIDS. ARV and the impact of non-compliance with ARV therapy on HIV pregnant women in the PMTCT program can result in individuals being late in doing prevention and treatment efforts or not doing any effort at all.

According to Widayanti's research [7] the proportion of mother to child transmission of more than $1 \%$ in the community is an indicator of generalized level conditions. This condition is an emergencing situation where the transmission from mother to baby is very high. Papua and Africa are examples of regions with generalized levels. PMTCT program is one of the government's efforts to prevent the spread of HIV transmission from mother to baby. Especially when to mother is pregnant or giving birth.

A small number of informants claimed to carry out risky sexual activities by changing patners and most of the informants engage in sexual activity with their patners after learning that they are HIV positive. Sexual activity is a part of the assessment of quality of life. Pleasant sexual activity will have a positive affect on the quality of one's life [8].

\section{2) Perception Of Severity}

The informants considered not feeling afraid after deciding to stop ARV therapy. Half of the informants said that they were not afraid after deciding to stop ARV therapy. That informants will be fine because they are taking herbs and also feel more trust in God the being anslaved by ARV medicine. The following excerpt statement from the informant:

"What else can I do, nurse? take a medicine like want to die, just live as is “. (N1, W1, April 9, 2020)

"I resigned myself to this situation, get better later too, I have drink herbs "(N7, W1, May 14, 2020)

The above questions are in line. With a triangulation of informant statement by health workers that HIV/AIDS sufferers who stop taking medicine feel healthy, normal and it's okey.

"Actually, they realize that they got HIV but feel without taking Arv medicine, they are fine it's okey, don't want to depend on medicine. Later if seriously ill, then regret it. Okay, I will be treated regularly if have been cured." (T4, FGD1, May 19, 2020).

This is in line with the research of Which states that the more someone feels at risk for an illness, that precautions to be taken will be better and vice verse the less risk someone has for an illness, there is no preventive action[9] According to Lawrence Green theory which states that the perception of the risk of contracting HIV will affect one's behavior in taking precautions. Half the informants said they didn't think their immunity dropped because they stopped taking ARV therapy and didn't feel the disease was severe. Half the informants surrender when death comes. The decision to stop ARV therapy actually makes the informant also feel scared and worried but helpless they just try to surrender to the God. The resignation shown by them is a psychological response that has not been able to accept its status as a person with HIV while in pregnancy. The result of this research are in line with research that Psychological responses that often occur in sufferers include: sad, shock, apathy, grieving anciety, fear of recurrence or death, low self-esteem, low self-perception, decree sad sel image, sel-isolation and depression [10]

\section{3) The Effects of Taking ARV}

Another obstacle is that some informants said that barriers to taking ARVs were a side effect of ARV medicines, which makes them reluctant to take medicine of ARV. The following expert statement from the informant:

“Dizzy if drink. “(N1, W1, April 9, 2020)

"I am nauseous, dizzy and unable to wake up." (N3, W1, May 5, 2020)

"I am rather dizzy, unable standing, if I don't drink it is fine." (N3,W1, May 5, 2020)

This was justified by the informant $\mathrm{T} 8$ that the informant felt nausea, vomiting, dizziness and no appetite. The following excerpt statement triangulation informant:

"We have called, forgot taking medicine? 
“Ouch. I can’t come alone, my body so weak, I am dizzy, nausea, vomit every taking that medicine. I have not appetite. (T8, FGD1, May 19, 2020)

Side effect of ARV treatment are all the symptoms that arise in the use of ARV medicine can be in the from of symptomatic symptoms that can be removed by administering medicines until the symptoms of toxicity that cause medicine use must be stopped.

This is in line with research which states that the side effect that are often felt by HIV/AIDS sufferers when undergoing ARV therapy are dizziness, nausea, vomiting, skin rashes, itching and halucinations [11]. This condition causes them to decide on treatment because they are unable to with stand the side effect that arise. According to another research that stating the incidence of side effects is what often causes the occurance of medicine withdrawal (loss to follow up) [12]

\section{4) Community Stigma And Discrimination}

Stigma and discrimination to HIV/AIDS sufferer still a major obstacle. The stigma comes from the mind of an individual or society who believes that HIV/AIDS is a result of immoral behavior and cannot be accepted by society. Most of the informants experienced stigma and discrimination from the environment and also from their own families. The following except statement from the informant:

"Actually who knows this is just the four of us but sometimes, neighbor talking about us, but I don't care. Usually I hear they say, don't pass there, they are HIV/AIDS sufferer at that home. Father once wanted to be angry to them, but I said let it go." (N1, W1, April 9, 2020)

"ya...neighbor said, you and your husband are HIV/AIDS sufferer aren't you? Are you lecherous? You have married but having and affair. Your husband also drunkard. Stay away from them. Later we got infected again. Them they ever said to us move from here. Here good people.” (N2, W1, April 23, 2020).

Most of informants stigmatized and discrimination from environment and also from their own family. Stigma and discrimination to HIV/AIDS sufferer still a major abstacle. Stigma comes from the mind of an individual or society who believes that HIV/AIDS is a result of inmoral behavior that is not appropriate in the community. As result many of them cover up their HIV status for fear of being excluded, experiencing discrimination, getting pregnant is not due to a legitimate husband and wife relationship. As research said the society actually still considers HIV/AIDS sufferer as someone who has deviant behavior and gives stigma to them. As a result many of them cover up their HIV[12][9]

From fear of being ostracized. These factors prevent HIV/AIDS sufferer from achieving success in implementing of PMTCT and according to statement head office of the Papua provincias health office, drg Aloysius Giyai, M.Kes on May 5, 2019 in Papua Today which says the high loss to follow up is a problem in the province of Papua and contributing factor among others, are still high stigma and discrimination against HIV/AIDS sufferer.

\section{5) Low Social Support}

Another obstacle is not getting support from family and society. Most of informants said that they don't getting support from family because they don't dare to open their status to them. Informants are afraid of being hated, stigmatizied and discriminated against by the family. The following quote from the informant:

“ nobody's family knows, just the two of us. We support each other, husband who always reminds me. We are afraid of being shunned by the family, so this is only a husband and wife secret." (N2,W1, April 23, 2020)

Social support is support from family and health workers. Most of informant said that they don't dare open their status to them. Informants are afraid of being hated, stigmatized and discriminated against by the family all informants claimed to have the full support of health workers such as always encouraging and motivating to take medicine, don't stress but always think positive [13][12].

In line with research said that although HIV/AIDS sufferer with loss to follow up received support from health workers while undergoing ARV therapy, they didn't get support from their partners and families. This is an obstacle for HIV/AIDS sufferer to reveal their status to their partners and family due to the fear of HIV/AIDS sufferer about rejection from their partners and family [9][12]

\section{CONCLUSION}

The results of this research reveal that the determinants of loss to follow up with ARV therapy are low vulnerability and perception of illness, stigma and discrimination that are still high and low social support. With the result of the above research we conclude that the determinants of loss to follow up of pregnant women with ARV therapy will add many new cases of HIV in Papua. So that it is not handled better, so target of three zero in 2030 will only remain as a discourse.

\section{REFERENCES}

[1] WHO, "Fact sheets Detail Hiv-Aids. https://www.who.int/newsroom/fact-sheets/detail/hiv-aids.” 2016.

[2] Kemenkes RI, Hasil Riset Kesehatan Dasar Tahun 2013. Jakarta: KemenkesRI, 2013.

[3] DinKes Provinsi Papua, Laporan Perkembangan Situasi HIV/AIDS di Papua. Jayapura: Dinkes Provinsi Papua, 2019.

[4] RSUDJAYAPURA, Data Profil RSUD Jayapura. Jayapura: RSUD JAYAPURA, 2019.

[5] J. L. Moleong, Metodologi Penelitian Kualitatif. Bandung City: Remaja Rosdakarya, 2012.

[6] Pollit\&Beck, Nursing research: generating and assending evidence nursing practice. Philadelphia: Wolters Kluwer, Lippincott Williams \& Wilkins, 2012.

[7] L. P. Widayanti and K. Kunci, "Evaluasi PMTCT ( Prevention Mother To Child Transmission ) pada IRT dengan HIV di Jatim Evaluation of PMTCT ( PREVENTION MOTHER TO CHILD TRANSMISSION ) Among Housewives with HIV in East Java," 2020 .

[8] A. Sajidah, W. I. Pangkahila, and J. A. Pangkahila, "Frekuensi Hubungan Seksual Tanpa Kondom Dengan Wanita Penjaja Seks (Wps) Tidak Berhubungan Dengan Tingkat Kepuasan Seksual Pria Beristri, Tetapi Berhubungan Dengan Risiko Infeksi Menular Seksual (Ims), " pp. 345-352, 2014.

[9] H. Tumangke, M. Tappy, and R. Kendek, "Faktor-Faktor Yang Mempengaruhi Efektivitas Pencegahan Penularan Hiv Dari Ibu Ke 
Anak (Ppia) Di Kota Jayapura," Unnes J. Public Heal., vol. 6, no. 4 , pp. 260-265, 2017.

[10] A. L. Dima, A. M. Schweitzer, K. R. Amico, and R. S. Wanless, "The Information-Motivation-Behavioral Skills Model of ART Adherence in Romanian Young Adults," J. HIV/AIDS Soc. Serv., vol. 12, no. 34, pp. 274-293, 2013.

[11] D. N. Rasmussenaeh et al., "Barriers and facilitators to antiretroviral therapy adherence among patients with HIV in Bissau, GuineaBissau: A qualitative study," African J. AIDS Res., vol. 12, no. 1, pp. $1-8,2013$.

[12] S. Wahyuni, "Kepatuhan ibu pada masa kehamilan, persalinan, dan nifas dalam pelaksanaan program pencegahan penularan HIV," J. Kebidanan dan Keperawatan Aisyiyah, vol. 12, no. 1, pp. 38-45, 2018
[13] D. S. C. et al., "Access to HIV prevention and care for HIV-exposed and HIV-infected children: a qualitative study in rural and urban Mozambique," BMC Public Health, vol. 14, p. 1240, 2014.

[14] K. J. Bahriyah, F. Monifa, P. dan Abdul, "Hubungan Pekerjaan Ibu Terhadap Pemberian ASI Eksklusif Pada Bayi,” J. Endur., vol. 2 (2)., p. 113-118., 2017.

[15] S. Rohan, H.H., Siyoto, KesehatanReproduksi. 2013.

[16] R. Oktora, "Gambaran Pemberian ASI Eksklusif pada Ibu Bekerja di Desa Serua Indah, Jombang, Tangerang Selatan,” J. Kesehat. Masy. Nas., vol. 4(1)., p. $30-40$ 